\title{
Phosphodiesterase I, A Novel Adhesion Molecule and/or Cytokine Involved in Oligodendrocyte Function
}

\author{
Babette Fuss, ${ }^{1}$ Hiroko Baba, ${ }^{3}$ Tom Phan, ${ }^{1}$ Vincent K. Tuohy, ${ }^{2}$ and Wendy B. Macklin ${ }^{1}$ \\ Departments of ${ }^{1}$ Neurosciences and ${ }^{2} /$ mmunology, Research Institute, The Cleveland Clinic Foundation, Cleveland, Ohio \\ 44195, and ${ }^{3}$ National Institute for Physiological Sciences, Okazaki, Aichi 444, Japan
}

\begin{abstract}
One of the more complex developmental processes occurring postnatally in the CNS is the formation of the myelin sheath by oligodendrocytes. To examine the molecular events that take place during myelination, we isolated oligodendrocyte-derived cDNA clones, one of which $(p 421 . \mathrm{HB})$ represents a putative alternatively spliced isoform of rat brain-specific phosphodiesterase I (PD-I $\alpha$ ) and a species homolog of the human cytokine autotaxin. Analysis of the structural composition of the $\mathrm{p} 421 . \mathrm{HB} / \mathrm{PD}-\mathrm{l} \alpha$ protein suggests a transmembrane-bound ectoenzyme, which, in addition to the phosphodiesterase-active site contains presumed cell recognition and $\mathrm{Ca}^{2+}$-binding domains. Consequently, it may be involved in extracellular signaling events. Expression of p421.HB/PD- $\alpha$ is enriched in brain and spinal cord, where its mRNA can be detected in oligodendrocytes and in cells of the choroid plexus. Expression in the
\end{abstract}

brain increases during development with an intermediate peak of expression around the time of active myelination and maximal expression in the adult. We have identified four presumably alternatively spliced isoforms, two of which appear to be CNSspecific. Decreased levels of p421.HB/PD-l $\alpha$ mRNA in the dysmyelinating mouse mutant jimpy, but not shiverer, suggest a role for $\mathrm{p} 421 . \mathrm{HB} / \mathrm{PD}-\mathrm{l} \alpha$ during active myelination and/or late stages of oligodendrocyte differentiation. Furthermore, p421.HB/PD-I $\alpha$ mRNA levels were reduced in the CNS at onset of clinical symptoms in experimental autoimmune encephalomyelitis. These data together implicate the importance of p421.HB/PD-l $\alpha$ in oligodendrocyte function, possibly through cell-cell and/or cell-extracellular matrix recognition.

Key words: phosphodiesterase; oligodendrocyte; myelin; cell adhesion; cytokine; EAE
Proper function of the mammalian nervous system not only requires the delicate control of neuronal migration and differentiation during embryonic development but also the precise regulation of one of the most complex postnatal developmental steps, myelination. Understanding myelination is additionally important, because the pathogenesis of human demyelinating diseases, such as multiple sclerosis, is still unclear. A number of animal models, such as rodent dysmyelinating mutants (for review, see Nave, 1994) and experimental autoimmune encephalomyelitis (EAE) (Martini and McFarland, 1995; Tsunoda and Fujinami, 1996), provide valuable tools to address different aspects of myelination and remyelination. However, detailed insight into the cellular biology of the oligodendrocyte, the myelin-forming cell of the CNS, is needed to obtain a comprehensive picture of the complex mechanisms that lead to normal myelin sheath formation or to insufficient myelination and myelin breakdown under pathological conditions. Within the past decade oligodendrocytespecific proteins and their genes have been studied extensively (for review, see Campagnoni and Macklin, 1988; Lemke 1988; Mikoshiba et al., 1991; Ikenaka and Kagawa, 1995), but despite these investigations, the precise mechanism of myelination is still poorly understood.

Received June 30, 1997; revised Aug. 28, 1997; accepted Sept. 11, 1997.

This work was supported by Grants from the National Multiple Sclerosis Society (W.B.M. and V.K.T.) and National Institutes of Health (V.K.T.) and by postdoctoral fellowships from the National Multiple Sclerosis Society (H.B. and B.F.). We thank Justin Johnson for technical assistance, Dr. J. Drazba for assistance with confocal microscopy, and Dr. A. Nishiyama for helpful and encouraging discussions and critically reading this manuscript.

Correspondence should be addressed to Dr. Babette Fuss, The Cleveland Clinic Foundation, Department of Neurosciences, NC-3, 9500 Euclid Avenue, Cleveland, $\mathrm{OH} 44195$.

Copyright (C) 1997 Society for Neuroscience $\quad 0270-6474 / 97 / 179095-09 \$ 05.00 / 0$
In studies designed to identify novel genes that could potentially be important during oligodendrocyte differentiation and myelin sheath formation, several cDNA clones were obtained by differential cloning techniques (Baba et al., 1994). One of these cDNA clones, p421.HB, represents a putative alternatively spliced isoform of rat brain-specific phosphodiesterase I/nucleotide pyrophosphatase (Narita et al., 1994). Phosphodiesterase I (oligonucleate 5' -nucleotidohydrolase; EC 3.1.4.1.) is a membrane-bound glycoprotein that catalyzes the hydrolysis of various nucleotide polyphosphates. Sequence analysis for rat brain-specific phosphodiesterase I revealed, in addition to the phosphodiesterase homologous region, two somatomedin B domains and an EF hand-like motif. Recently, autotaxin was isolated as a new cytokine from human tumor cell lines $(\mathrm{Mu}-$ rata et al., 1994; Lee et al., 1996), and it was shown to represent the human homolog of rat brain-specific phosphodiesterase I (Kawagoe et al., 1995; Lee at al., 1996). A soluble form of autotaxin, generated through proteolytic cleavage, was shown to be involved in a G-protein-coupled stimulation of chemotactic and chemokinetic responses of tumor cells. The functional importance of phosphodiesterase I/autotaxin in the CNS has been unclear.

To gain knowledge about possible functional roles of phosphodiesterase I in the CNS, we analyzed the expression of phosphodiesterase I isoforms during development and in different cell types of the normal rat CNS. We have focused our subsequent studies on phosphodiesterase I expression in oligodendrocytes, because the CNS-specific form of the protein appears to be enriched in oligodendrocytes. Thus, we have characterized phosphodiesterase I mRNA levels in the CNS of dysmyelinating mouse mutants and in the presence of inflammatory lesions in 
EAE. The data presented here propose a functional role for phosphodiesterase I during myelination in the CNS.

\section{MATERIALS AND METHODS}

Animals. For in situ hybridization 4-d-old, 21-d-old, and adult (older than 60 d) Sprague Dawley rats were analyzed (Harlan Sprague Dawley, Indianapolis, IN). For analysis of dysmyelinating mouse mutants, 21-dold shiverer, jimpy, and trembler mice were used. All mutant and agematched control mice were bred at the departmental animal facilities Female $(\mathrm{SWR} \times \mathrm{SJL}) \mathrm{F}_{1}\left(\mathrm{H}-2^{\mathrm{q}, \mathrm{s}}\right)$ mice used for induction of EAE were bred at the Research Institute of the Cleveland Clinic Foundation by mating SWR/J $\left(\mathrm{H}-2^{\mathrm{q}}\right)$ females with SJL/J $\left(\mathrm{H}-2^{\mathrm{s}}\right)$ males purchased from The Jackson Laboratory (Bar Harbor, ME).

Isolation and sequence analysis of cDNA clones. The cDNA clone $\mathrm{p} 421$.HB represents one of the clones isolated by differential and subtractive screening of an oligodendrocyte-derived cDNA library (Baba et al., 1994). Briefly, oligodendrocyte cultures were prepared by the method of McCarthy and DeVellis (1980), and poly(A) ${ }^{+}$RNA isolated from these cultures was used for construction of a cDNA library into the vector $\lambda$ ZAPII (Stratagene, La Jolla, CA). Differential (rat brain vs liver) and subtractive screening (rat brain minus spleen) of this cDNA library yielded 10 cDNA clones that were shown to be brain-enriched by Northern blot analysis.

Sequence analysis and nucleotide and amino acid homology searches were performed using the BLAST algorithm (Altschul et al., 1990) as provided by the National Center for Biotechnology Information (Bethesda, MD), and for protein sequence pattern searches the Search Launcher provided by the Baylor College of Medicine (Houston, TX) was used.

Northern blot analysis. RNA was isolated by the single-step RNA isolation method developed by Chomczynski and Sacchi (1987). Ten micrograms of total RNA were separated on $1 \%$ agarose gels containing $2.2 \mathrm{M}$ formaldehyde. RNA was transferred to MagnaGraph nylon membranes (Micron Separations Inc., Westboro, MA) and hybridized at $42^{\circ} \mathrm{C}$ with the complete cDNAs of p421.HB and cyclophilin (Danielson et al., 1988), labeled with $\left[{ }^{32} \mathrm{P}\right] \mathrm{dCTP}$ using the High Prime labeling kit according to the manufacturer's instructions (Boehringer Mannheim, Indianapolis, IN). Blots were analyzed using autoradiography and phosphorimaging techniques in combination with the software programs Image Quant (Molecular Dynamics, Sunnyvale, CA) and Excel (Microsoft).

In situ hybridization. For in situ hybridization, digoxigenin-labeled cRNA probes (sense and antisense) were prepared using T3-, T7-, or Sp6-RNA polymerase according to the manufacturer's instructions (Boehringer Mannheim) (also see Krieg and Melton, 1984) and hydrolyzed under alkaline conditions to obtain fragments of $\sim 250 \mathrm{bp}$ in length. The $\mathrm{p} 421 . \mathrm{HB} / \mathrm{phosphodiesterase} \mathrm{I} \alpha(\mathrm{PD}-\mathrm{I} \alpha)$-specific probe contained the complete p421.HB insert of $1.6 \mathrm{~kb}$; the probe specific for proteolipid protein (PLP) covered the entire coding region (Sorg et al., 1987). Fixation and hybridization of fresh frozen cryostat sections was performed in a modified version of methods described elsewhere (Bartsch et al., 1992, Fuss et al., 1993, Panoskaltsis-Mortari and Bucy, 1995). Briefly, cryostat sections $(10-12 \mu \mathrm{m})$ were thaw-mounted onto Superfrost/plus slides (Fisher Scientific, Pittsburgh, PA) and fixed in 3\% paraformaldehyde in PBS, $\mathrm{pH}$ 7.3. After treatment with $0.1 \mathrm{M} \mathrm{HCl}$ and subsequent acetylation, sections were prehybridized at $37^{\circ} \mathrm{C}$ in the presence of $50 \%$ formamide. Hybridizations were performed in the presence of $50 \%$ formamide at $55^{\circ} \mathrm{C}$. After RNase treatment $[40 \mu \mathrm{g} / \mathrm{ml} \mathrm{STE}(500 \mathrm{~mm}$ $\mathrm{NaCl}, 20 \mathrm{~mm}$ Tris-HCl, $\mathrm{pH} 7.5$, and $1 \mathrm{~mm}$ EDTA], sections were washed in $0.2 \times$ SSC containing $50 \%$ formamide at $55^{\circ} \mathrm{C}$, and bound cRNA was detected using an alkaline phosphatase-coupled antibody to digoxigenin with subsequent color development in the presence of 4-nitroblue tetrazolium chloride/5-bromo-4-chloro-3-indolylphosphate and levamisol.

Cell cultures. Mixed glial cell cultures and oligodendrocyte cultures used for reverse transcription-PCR (RT-PCR) analysis were prepared from the cerebrum of 1- to 3-d-old rats using the method described by McCarthy and DeVellis (1980). Astrocyte cultures were obtained from mixed glial cultures after oligodendrocytes were shaken off.

Oligodendrocyte cultures used for combined in situ hybridization and immunocytochemistry were prepared from the cerebrum of postnatal rats (1-3 d old) by immunopanning (Barres et al., 1992) using the A2B5 antibody (kindly provided by A. Nishiyama, Cleveland Clinic Foundation) (Eisenbarth et al., 1979). Briefly, after removal of the meninges, tissue was minced in HBSS (Life Technologies, Grand Island, NY) and incubated for $30 \mathrm{~min}$ at $37^{\circ} \mathrm{C}$ in $0.06 \%(\mathrm{w} / \mathrm{v})$ trypsin and $0.06 \%(\mathrm{w} / \mathrm{v})$ pancreatin. Cells were collected by centrifugation and resuspended in
DMEM (Life Technologies) containing 10\% fetal calf serum (FCS). The cell suspension was transferred to petri dishes coated with the A2B5 antibody (suspension from three brains per dish, $100 \mathrm{~mm}$ diameter) and incubated for $30 \mathrm{~min}$ at $37^{\circ} \mathrm{C}$. Nonadherent cells were washed off, and adherent cells, enriched for A2B5-positive oligodendrocyte progenitor cells, were plated onto poly-L-lysine (Sigma, St. Louis, MO)-coated coverslips after removal from the A2B5-coated dish. Cells were cultured overnight in DMEM/10\% FCS; medium was exchanged to DMEM containing $1 \times \mathrm{N} 2$ supplement (Life Technologies) and platelet-derived growth factor (R \& D Systems, Minneapolis, MN) at a concentration of $10 \mathrm{ng} / \mathrm{ml}$ for stimulation of progenitor cell proliferation. After $2 \mathrm{~d}$ cells were cultured in DMEM containing $1 \times \mathrm{N} 2$ supplement and 3,3'-5triiodo-L-thyronine $(10 \mathrm{ng} / \mathrm{ml}$; Sigma) to allow oligodendrocyte progenitor cells to differentiate. Cells were analyzed for $\mathrm{p} 421 . \mathrm{HB} / \mathrm{PD}-\mathrm{I} \alpha$ mRNA expression after $8 \mathrm{~d}$ in culture.

Combined in situ hybridization and immunocytochemistry. Oligodendrocyte cultures were fixed in 3\% paraformaldehyde in PBS for $1 \mathrm{hr}$. In situ hybridization was performed as described for the brain sections above, except that fixed cells were hybridized at $37^{\circ} \mathrm{C}$, and the RNase treatment after hybridization was omitted. For detection of the digoxigenin-labeled cRNA probes anti-digoxigenin Fab fragments from sheep (Boehringer Mannheim) in combination with a biotin-coupled anti-sheep IgG antibody (Jackson ImmunoResearch, West Grove, PA) and fluorescein avidin D (Vector Laboratories, Burlingame, CA) was used. Subsequently, cells were incubated with a polyclonal anti-2 $2^{\prime}, 3^{\prime}-$ cyclic nucleotide $3^{\prime}$-phosphodiesterase (CNP) antibody (kindly provided by T. Kurihara, Soka University, Tokyo, Japan) (Kurihara et al., 1992), followed by an incubation with a Texas Red-coupled anti-rabbit IgG antibody (Jackson ImmunoResearch). Fluorescent signals were analyzed by a confocal laser scanning microscope (Aristoplan; Leica, Deerfield, IL). Confocal images represent optical sections of $\sim 1 \mu \mathrm{m}$ and an average of 15 line scans.

$R T-P C R$. Ten micrograms of total RNA of each tissue were used for reverse transcription using Superscript II (Life Technologies) as described by Frohman (1994) in the classic protocol for rapid amplification of cDNA ends. For amplification, $2.5-10 \%$ of the reverse transcription reaction was used with the following sets of primers: primer 1 (sense), located at nucleotides (nt) 1746-1773 of rat phosphodiesterase I (Narita et al., 1994); primer 3 (antisense), nt 2056-2031, which are flanking the proposed alternatively spliced 75 bp sequence (nt 1862-1937); and primer 2 (sense) at nt 1868-1895, which is located within the proposed alternatively spliced sequence. The amplification reaction was performed in a final volume of 50 $\mu \mathrm{l}$ in $1 \times$ PCR buffer $\left(16.6 \mathrm{~mm}\left[\mathrm{NH}_{4}\right]_{2} \mathrm{SO}_{4}, 67 \mathrm{~mm}\right.$ Tris, $\mathrm{pH} 8.8$, and $6.7 \mathrm{~mm}$ $\mathrm{MgCl}_{2}$ ), 10\% DMSO, $1.5 \mathrm{~mm}$ each dNTP, 25 pmol each of the primer oligonucleotides, and $1.25 \mathrm{U}$ of Taq polymerase. After 30 cycles (1 min, $94^{\circ} \mathrm{C} ; 1 \mathrm{~min}, 55^{\circ} \mathrm{C}$; and $2 \mathrm{~min} 68^{\circ} \mathrm{C}$ ) one-third of the reaction was analyzed on a $3.5 \%$ NuSieve GTG agarose gel (FMC Bioproducts, Rockland, ME). Ratios of amplification products obtained in each of the reactions were calculated by intensity determinations using scanned images of ethidium bromide-stained gels of at least three experiments and the image analysis software NIH-Image (National Institutes of Health).

Induction of EAE. For EAE induction, $(\mathrm{SWR} \times \mathrm{SJL}) \mathrm{F}_{1}$ mice were immunized with the encephalitogenic peptide p139-151 (HSLGKWLGHPDKF) of proteolipid protein (Tuohy et al., 1989) as described previously (Yu et al., 1996). Each mouse was injected on day 0 subcutaneously with $100 \mathrm{nmol}$ of peptide plus $400 \mu \mathrm{g}$ of Mycobacterium tuberculosis H37RA (Difco, Detroit, MI) in $200 \mu \mathrm{l}$ of $\mathrm{H}_{2} \mathrm{O}$ /incomplete Freund's adjuvant (Difco) emulsion and on days 0 and 3 intraveniously with $0.6 \times 10^{10}$ Bordetella pertussis bacilli (Michigan Department of Public Health, Lansing, MI). Mice were weighed and examined daily, and animals were killed for further analysis at onset of clinical signs: clinical grades 1 (decreased tail tone or slightly clumsy gait) and 2 (tail atony, moderately clumsy gait, and/or poor righting ability). Control animals, which were injected with BSA, were taken at each time point for each affected animal.

RNase protection assay. RNase protection assay (RPA) was performed essentially as described by Saccomanno et al. (1992). Briefly, cRNA fragments were synthesized in the presence of $50 \mu \mathrm{Ci}$ of $\left[{ }^{32} \mathrm{P}\right] \mathrm{UTP}$ and $100 \mu \mathrm{M}$ (for p421.HB), $200 \mu \mathrm{M}$ (for PLP), or $300 \mu \mathrm{M}$ (for cyclophilin) UTP from $0.5 \mu \mathrm{g}$ (for p421.HB and PLP) or $0.25 \mu \mathrm{g}$ (for cyclophilin) of linearized template DNA using T7 RNA polymerase according to the manufacturer's instructions (Promega, Madison, WI). The p421.HB template was obtained by RT-PCR on cellular RNA isolated from mouse brains. The p421.HB/PD-I $\alpha$ cRNA probe represented $147 \mathrm{nt}$ of the mouse coding region (nt 2069-2216 in the rat PD-I $\alpha$ sequence; Narita et 

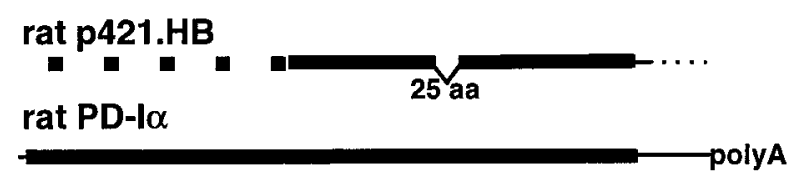

human PD-I $\alpha$

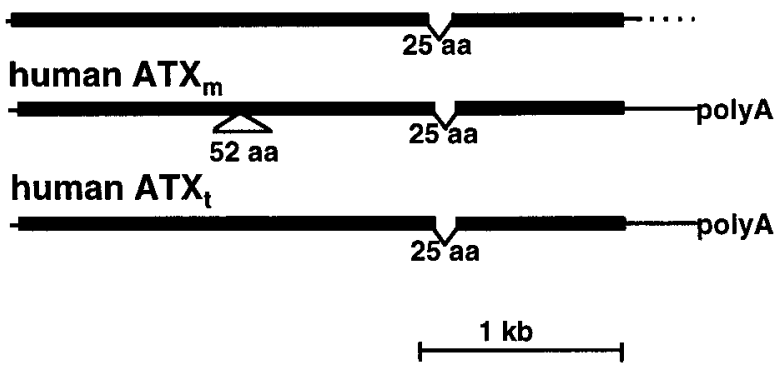

Figure 1. Comparison of PD-I $\alpha /$ ATX cDNA clones. Sequence analysis revealed identity of the partial cDNA clone $\mathrm{p} 421 . \mathrm{HB}$ with the $\mathrm{C}$-terminal coding region of rat PD-I $\alpha$ plus $3^{\prime}$-untranslated sequences. However, in the cDNA clone, p421.HB sequences coding for amino acids 596-615 (25 $a a)$ of rat PD-I $\alpha$ are missing. In addition, human PD-I $\alpha$ is identical to human teratocarcinoma-derived autotaxin $\left(A T X_{t}\right)$, whereas human melanoma-derived autotaxin $\left(A T X_{m}\right)$ has an additional 52 amino acid (52 aa) insertion. Coding regions are represented by thick lines; $5^{\prime}-$ and 3 '-untranslated sequences are represented by thin lines.

al., 1994); the probe for PLP represented $228 \mathrm{nt}$ of the $3^{\prime}$-untranslated sequences (nt 1242-1470 of PLP; Sorg et al., 1987); and the probe for cyclophilin covered $290 \mathrm{nt}$ of the coding region (nt 48-338; Danielson et al., 1988). Ten micrograms of total RNA were hybridized in $80 \%$ formamide, $40 \mathrm{~mm}$ PIPES, $\mathrm{pH} 6.5,400 \mathrm{~mm} \mathrm{NaCl}$, and $1 \mathrm{~mm}$ EDTA at $45^{\circ} \mathrm{C}$ with $1 \times 10^{6}$ and $5 \times 10^{5} \mathrm{cpm}$ of the labeled cyclophilin and p421.HB or PLP cRNA, respectively. "Non-hybridized" RNA was digested with ribonuclease T2 (Life Technologies) at concentrations of 20-50 U/ml for $1 \mathrm{hr}$ at $37^{\circ} \mathrm{C}$. Protected RNA duplexes were separated on a $6 \%$ polyacrylamide/urea gel. Further analysis of three independent experiments using RNA of at least two animals each was performed using autoradiography and phosphorimaging techniques in combination with the software programs Image Quant (Molecular Dynamics) and Excel (Microsoft).

\section{RESULTS}

p421.HB/PD-I $\alpha$ represents a member of the somatomedin/phosphodiesterase family of proteins

To get new insight into the molecular basis of oligodendrocyte function, an oligodendrocyte-derived cDNA clone, designated p421.HB, was further characterized. p421.HB represents a partial cDNA clone with sequence identity to the $3^{\prime}$-end of rat brainspecific PD-I $\alpha$ (Narita et al., 1994). The common sequences between $\mathrm{p} 421 . \mathrm{HB}$ and $\mathrm{PD}-\mathrm{I} \alpha$ encompass the region coding for amino acids 391-885 of PD-I $\alpha$ through the first 125 nucleotides of the 3 '-untranslated region. The $75 \mathrm{bp}$ region coding for amino acids 596-615 of PD-I $\alpha$ is absent in the p421.HB cDNA (Fig. 1, $25 \mathrm{aa}$ ). Further homology analysis by us and others (Murata et al., 1994; Narita et al., 1994; Kawagoe et al., 1995; Lee et al., 1996) revealed identity of human PD-I $\alpha$ with human autotaxin (ATX), with the exception of another likely alternatively spliced sequence present in melanoma-derived autotaxin (Fig. 1, $52 \mathrm{aa}$ ). Using this information, we suggest that $\mathrm{p} 421$.HB represents an alternatively spliced isoform of PD-I $\alpha$. We refer to the PD-I $\alpha$ isoforms as $\mathrm{p} 421 . \mathrm{HB} / \mathrm{PD}-\mathrm{I} \alpha$. Common structural features of $\mathrm{p} 421 . \mathrm{HB} / \mathrm{PD}-\mathrm{I} \alpha /$ ATX, PC-1 (van Driel and Goding, 1987; Buckley et al., 1990), and the gp130RB13-6 antigen (Deissler et al., 1995) define the somatomedin/phosphodiesterase family of proteins, which is characterized by the presence of two somatomedin B domains, a phosphodiesterase-active site, and an EF hand-like motif in the
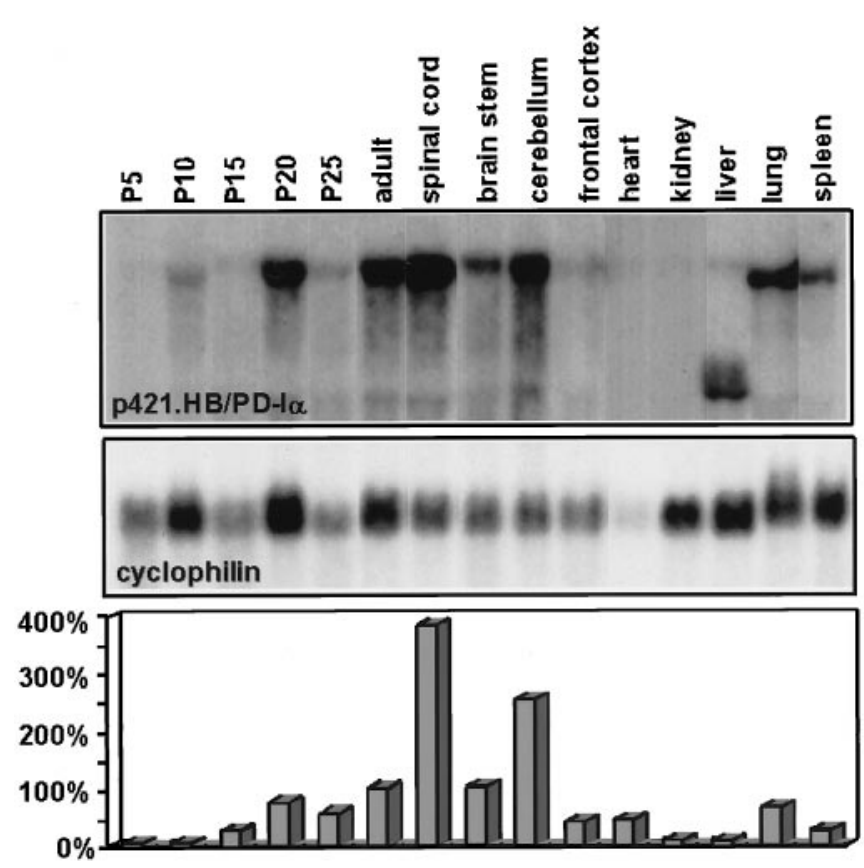

Figure 2. Northern blot analysis of mRNA prepared from different adult rat tissues and rat brain of different developmental stages [postnatal days 5 (P5), 10 (P10), 15 (P15), 20 (P20) and 25 (P25) and adult $]$ using the p421.HB cDNA clone (Fig. 1) and a cyclophilin-specifc cDNA probe. Ten micrograms of total RNA were separated on a $1.2 \%$ formaldehyde gel and hybridized with ${ }^{32} \mathrm{P}$-labeled DNA fragments specific for $\mathrm{p} 421 . \mathrm{HB} / \mathrm{PD}-\mathrm{I} \alpha$ and cyclophilin. For quantification Northern blots were analyzed by phosphorimaging techniques, and mRNA levels were normalized to cyclophilin. For the diagram at the bottom the mRNA level in adult brain was set to $100 \%$.

extracellular part of the proposed type II (cytoplasmic N terminus) membrane proteins.

p421.HB/PD-I $\alpha$ is expressed predominantly in the CNS, in which expression increases toward adulthood with a peak around postnatal day 20

Northern blot analyses were performed to characterize the tissue-specific and developmental expression of p421.HB/ PD-I $\alpha$ (Fig. 2). As shown for rat brain-specific PD-I $\alpha$ (Narita et al., 1994), the p421.HB/PD-I $\alpha$ cDNA hybridized to an mRNA of $\sim 3.3 \mathrm{~kb}$. In the adult, p421.HB/PD-I $\alpha$ mRNA was expressed predominantly in the CNS (brain and spinal cord) with additional signals detectable especially in heart, lung, and spleen. The lower molecular weight band in adult liver might be explained by hybridization to another, yet unidentified, $\mathrm{PD}-\mathrm{I} \alpha$ isoform, or it may result from cross-hybridization with a homologous mRNA, possibly coding for another member of the somatomedin/phosphodiesterase protein family. Highest expression within the adult CNS was observed in areas enriched in oligodendrocytes (spinal cord and brainstem but not frontal cortex). The high levels of $\mathrm{p} 421 . \mathrm{HB} / \mathrm{PD}-\mathrm{I} \alpha$ mRNA in adult cerebellum are likely to be derived from choroid plexus epithelial cells present in the tissue used for RNA isolation (Fig. 3). During rat brain development, p421.HB/PD-I $\alpha$ was expressed by postnatal day 5 , and expression increased toward adulthood with an intermediate peak around postnatal day 20 , when active myelination takes place. 

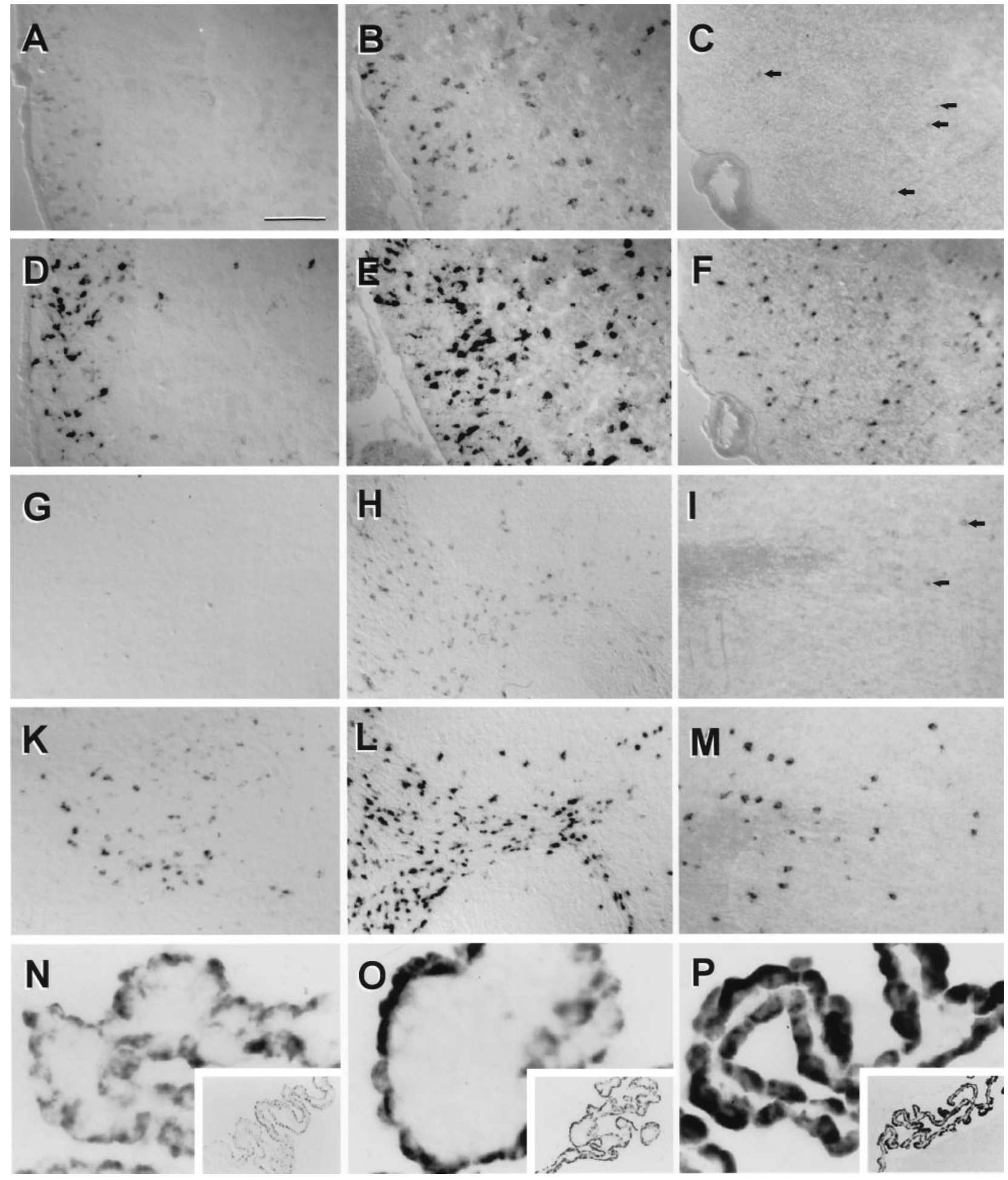

Figure 3. Localization of p421.HB/PD-I $\alpha$ mRNA $(A-C, G-I, N-P)$ in comparison with PLP mRNA $(D-F, K-M)$ in the ventral horn of the spinal cord $(A-F)$, cerebellum $(G-M)$, and choroid plexus of the lateral ventricle $(N-P)$ of postnatal day $4(A, D, G, K, N)$ and $21(B, E, H, L, O)$ and adult $(C, F$, $I, M, P$ ) rats. p421.HB/PD-I $\alpha$ mRNA-positive cells were observed in white matter areas in a distribution similar to PLP mRNA-positive cells (compare $A$ with $D, B$ with $E, C$ with $F, G$ with $K$, and $H$ with $L, I$ with $M$ ), although p421.HB/PD-I $\alpha$ mRNA expression appears to be lower than the one of PLP. In contrast to PLP, at postnatal day 4 no p421.HB/PD-I $\alpha$ mRNA-positive cells were detectable at the base of the cerebellum (compare $G$ with $K$ ). In the spinal cord, however, p421. HB/PD-I $\alpha$ mRNA-positive cells were visible more restricted to the area close to the outer surface $(A)$ than PLP mRNA-positive cells $(D)$. In the adult, only very few p421.HB/PD-I $\alpha$ mRNA-positive cells were detectable, which were localized in and close to white matter tracts (arrows in $C, I$ ), where PLP-positive cells can also be detected (compare $C$ with $F, I$ with $M$ ). Additional strong p421.HB/PD-I $\alpha$ mRNA-positive signals were detectable in cells of the choroid plexus, with increasing levels of expression with age $(N-P)$. Sections hybridized with sense cRNA probes showed no labeling. Scale bars (in $A$ ): $A, B, D, E, 100 \mu \mathrm{m} ; C, F, 210 \mu \mathrm{m} ; G, H, 110 \mu \mathrm{m} ; H, L, 130 \mu \mathrm{m} ; I, M, 200 \mu \mathrm{m} ; N-P, 20 \mu \mathrm{m} ; N-P$, insets, $410 \mu \mathrm{m}$. 


\section{p421.HB/PD-I $\alpha$ mRNA is expressed in} oligodendrocytes and choroid plexus epithelial cells

In situ hybridization was performed to determine the cellular source of $\mathrm{p} 421 . \mathrm{HB} / \mathrm{PD}-\mathrm{I} \alpha$ mRNA during development of the CNS. In the spinal cord $\mathrm{p} 421 . \mathrm{HB} / \mathrm{PD}-\mathrm{I} \alpha$ mRNA-positive cells showed a distribution similar to cells positive for PLP mRNA, coding for the major myelin protein of the CNS (Fig. 3, compare $A-C$ with $D-F)$. At postnatal day 4, p421.HB/PD-I $\alpha$-positive cells were detectable ventrally, close to the spinal cord surface (Fig. $3 A$ ) and in the dorsal column (not shown). In 21-d-old rat spinal cord the number of $\mathrm{p} 421 . \mathrm{HB} / \mathrm{PD}-\mathrm{I} \alpha$ mRNA-expressing cells was increased, and these cells were found in white as well as in gray matter (Fig. $3 B$ ). Expression of p421.HB/PD-I $\alpha$ mRNA appeared to decrease toward adulthood, with only a few p421.HB/PD-I $\alpha$ mRNA-positive cells being detectable (Fig. 3C, arrows). In the brain of 21-d-old rats $\mathrm{p} 421 . \mathrm{HB} / \mathrm{PD}-\mathrm{I} \alpha$ mRNA-positive signals were obtained in all white matter areas [cerebellum (Fig. $3 G-I$ ); corpus callosum, fimbria, and fornix (data not shown)]. In contrast to the spinal cord, however, no $\mathrm{p} 421 . \mathrm{HB} / \mathrm{PD}-\mathrm{I} \alpha$ signals were detectable at postnatal day 4 in white matter areas of the brain, although differentiating oligodendrocytes could already be identified by PLP expression (Fig. 3, compare $G$ and $K$ ). As in the spinal cord, the number of p421.HB/PD-I $\alpha$ mRNA-positive cells in white matter was higher in postnatal day 21 than in adult brain, where only a few positive cells were visible (Fig. 3I, arrows). The distribution and developmental regulation of $\mathrm{p} 421 . \mathrm{HB} / \mathrm{PD}-\mathrm{I} \alpha$ mRNA-positive cells in the CNS suggests that these cells are oligodendrocytes.

To establish this interpretation more conclusively, we performed in situ hybridization of cultured cells enriched for oligodendrocytes with a $\mathrm{p} 421 . \mathrm{HB} / \mathrm{PD}-\mathrm{I} \alpha \mathrm{cRNA}$ probe in combination with immunostaining for the oligodendrocyte-specific enzyme CNP (Fig. 4). The presence of double-labeled cells clearly demonstrates that $\mathrm{p} 421 . \mathrm{HB} / \mathrm{PD}-\mathrm{I} \alpha$ mRNA is expressed in differentiated oligodendrocytes, which express the earliest known myelination-specific protein, CNP. However, under the cell culture conditions used, only $\sim 10 \%$ of the CNP-positive cells were p421.HB/PD-I $\alpha$ mRNA-positive, and p421.HB/PD-I $\alpha$ mRNA expression levels of these oligodendrocytes were relatively low when compared with PLP (data not shown). These experiments also showed that the few astrocytes in these cultures were negative for p421.HB/PD-I $\alpha$ mRNA (also see RT-PCR data in Fig. 5). Because CNP expression is not restricted to one well defined developmental stage of the oligodendrocyte lineage, additional studies are necessary to more exactly define the time course of $\mathrm{p} 421 . \mathrm{HB} / \mathrm{PD}-\mathrm{I} \alpha$ mRNA expression during the process of differentiation from an A2B5-positive oligodendrocyte progenitor cell to a myelinating oligodendrocyte.

In addition to expression by oligodendrocytes, $\mathrm{p} 421 . \mathrm{HB} / \mathrm{PD}-\mathrm{I} \alpha$ mRNA was detected in the choroid plexus, with increasing levels of expression during development (see choroid plexus of the ventral ventricle in Fig. $3 N-P$ ). The cells of the choroid plexus could be identified as choroid plexus epithelial cells by combining immunofluorescence (Glut 1) and in situ hybridization (p421.HB/ PD-I $\alpha$ ) (data not shown). These data also showed that $\mathrm{p} 421 . \mathrm{HB} /$ $\mathrm{PD}-\mathrm{I} \alpha$ is not expressed in ependymal cells lining the ventricles.

\section{p421.HB/PD-I $\alpha$ mRNA is expressed in at least four isoforms, of which two appear to be expressed exclusively in the CNS}

As discussed earlier (Fig. 1), homologies between the sequences of rat PD-I $\alpha$ (Narita et al., 1994) and the cDNA clone p421.HB
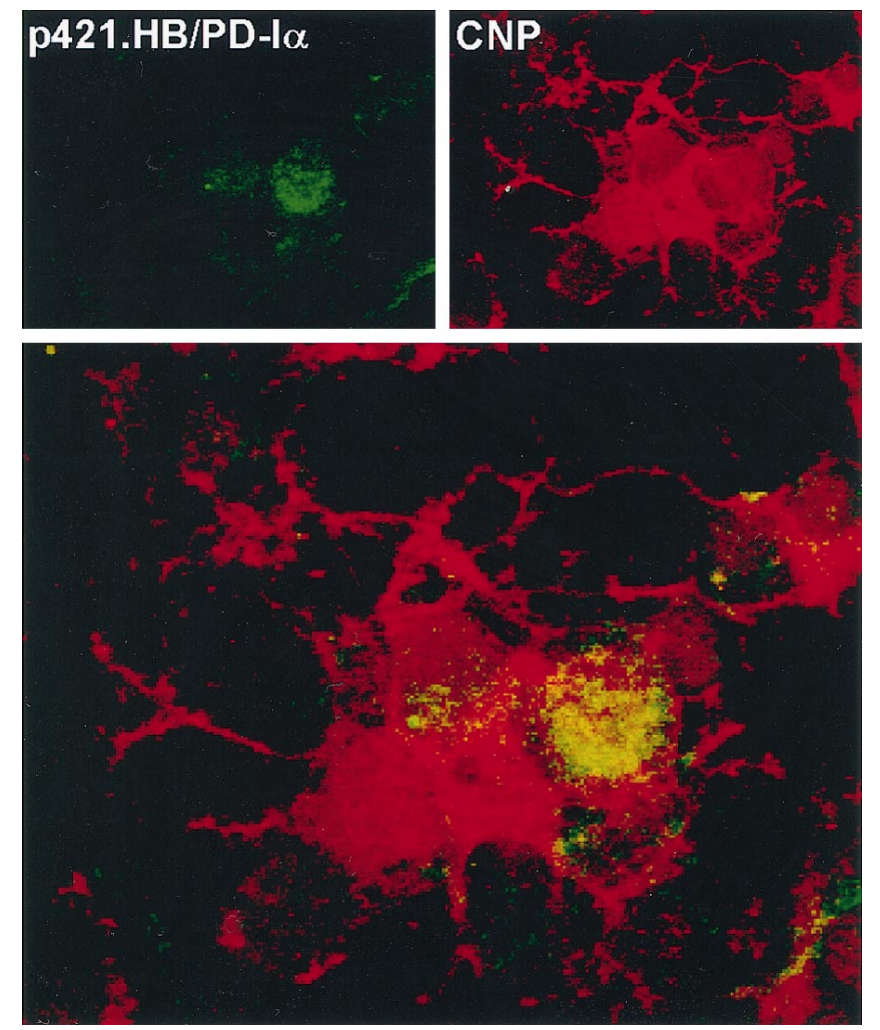

Figure 4. Analysis of $\mathrm{p} 421 . \mathrm{HB} / \mathrm{PD}-\mathrm{I} \alpha$ mRNA expression in cultured oligodendrocytes by confocal imaging. The expression of $\mathrm{p} 421 . \mathrm{HB} / \mathrm{PD}-\mathrm{I} \alpha$ mRNA by oligodendrocytes could be directly demonstrated by combined in situ hybridization and immunocytochemistry. In 8-d-old cultures of panned oligodendrocytes cells positive for both 421 .HB/PD-I $\alpha$ mRNA (fluorescein, green) and CNP (Texas Red, red) could be detected, although not all of the CNP-positive cells were positive for $\mathrm{p} 421$.HB/PD-I $\alpha$ mRNA. Controls hybridized with sense cRNA probes were negative.

suggested that $\mathrm{p} 421 . \mathrm{HB}$ represents an isoform of rat brain-specific $\mathrm{PD}-\mathrm{I} \alpha$ most likely generated by alternative splicing. To demonstrate the existence of the two predicted $\mathrm{p} 421 . \mathrm{HB} / \mathrm{PD}-\mathrm{I} \alpha$ isoforms, we performed RT-PCR using two pairs of oligonucleotides and RNA from different rat tissues, as well as from brains of animals of different developmental ages (Fig. 5). Subsequently the RT-PCR products were cloned and sequenced. In the adult, only RNA from the CNS yielded amplification products of 309 and $297 \mathrm{bp}$, both of which contained the putative 75 bp exon, missing in $\mathrm{p} 421 . \mathrm{HB}$ and the published sequences of human autotaxin (Figs. 1, 5, compare $A$, adult lane, with $B$ ). In contrast, the shorter isoforms of $\mathrm{p} 421 . \mathrm{HB} /$ PD-I $\alpha$ (222 and 234 bp) appeared to be expressed more ubiquitously (Fig. $5 B$ ). In addition to the proposed 75 bp exon, a second presumably alternatively spliced sequence of 12 bp was identified, giving rise to amplification products of 297 and $222 \mathrm{bp}$ in length. The encoded amino acids of the proposed $12 \mathrm{bp}$ alternatively spliced exon are located 17 amino acids $\mathrm{N}$-terminal to the proposed $75 \mathrm{bp}$ exon and are present in all yet published cDNA sequences coding for $\mathrm{p} 421 . \mathrm{HB} / \mathrm{PD}-\mathrm{I} \alpha /$ autotaxin. This sequence of $12 \mathrm{bp}$ does not seem to be expressed in any unique tissue- or age-specific manner. During development, the brain-specific 75 bp sequence seemed to be regulated similarly to the entire $\mathrm{p} 421 . \mathrm{HB} / \mathrm{PD}-\mathrm{I} \alpha$ mRNA (Fig. $5 A$; and Northern blot using the 75 bp sequence as probe, data not shown). These data suggest that the 75 bp sequence was expressed only in the CNS, but these experiments could not distinguish between expression in oligodendrocytes and in choroid 
A

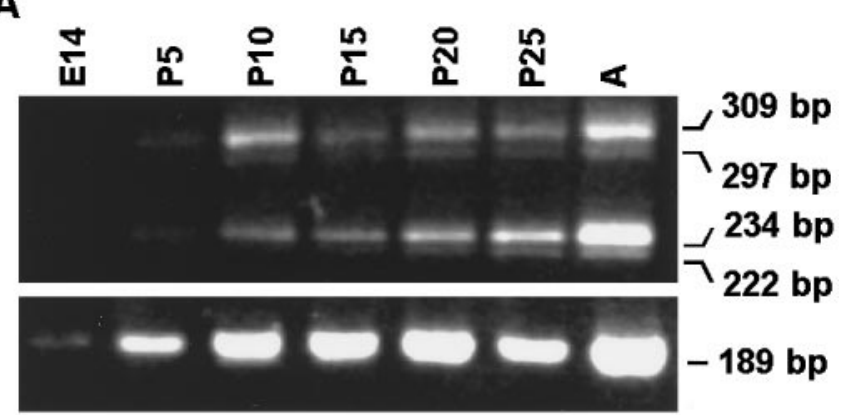

B

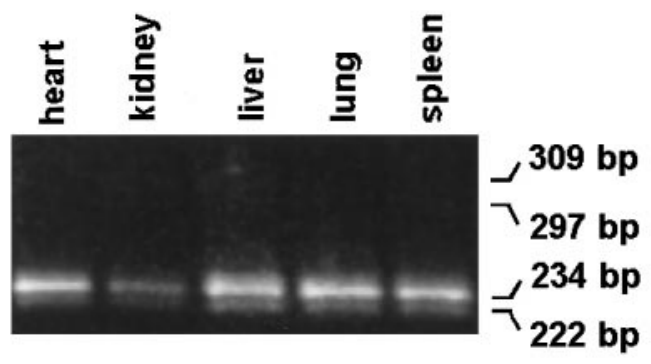

C

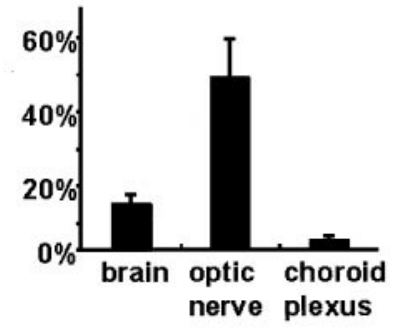

D

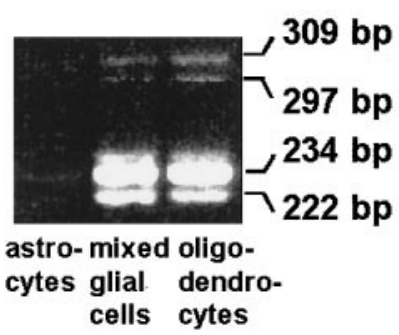

Figure 5. Characterization of $\mathrm{p} 421 . \mathrm{HB} / \mathrm{PD}-\mathrm{I} \alpha$ isoforms. The existence of alternatively spliced isoforms of $\mathrm{p} 421 . \mathrm{HB} / \mathrm{PD}-\mathrm{I} \alpha$ could be demonstrated by RT-PCR using two primer pairs: one, in which both oligonucleotides flanked the proposed alternatively spliced 75 bp (Fig. 1, 25 aa) sequence $(A$, top panel, $B, D)$, and a second one in which one oligonucleotide flanked the $75 \mathrm{bp}$ region, and the other one was located within this 75 region $(A$, bottom panel $)$. RNA was derived from rat brains of different developmental ages $[A$, embryonic day 14 (E14), postnatal days 5 (P5), 10 $(P 10), 15(P 15), 20(P 20)$, and $25(P 25)$, and adult $(A)]$, different adult rat tissues $(B)$, different CNS regions of adult rats $(C)$, and from cells in culture $(D)$. The amplification products were analyzed on $3.5 \%$ agarose gels (ethidium bromide-stained gels are shown in $A, B, D$ ). For quantification $(C)$ scanned images were used and analyzed with the NIH-Image software. Percentages of the two longer isoforms (309 bp, $297 \mathrm{bp}$ ), including the alternatively spliced 75 bp exon [coding for amino acids 551-557 (AETGKFRGSKHENKKNLNGSVEPRK) in rat PD-I $\alpha$ ], are given in $C$ (total p421.HB/PD-I $\alpha$ expression $=100 \%)$. The molecular weights of the fragments obtained are marked at the right margins in base pairs.

plexus epithelial cells. Detailed, more quantitative analyses of additional RT-PCR data showed that in a CNS area devoid of choroid plexus epithelial cells and enriched for oligodendrocytes (optic nerve) the brain-specific isoforms were abundantly expressed, whereas in the adult choroid plexus the CNS-specific isoforms were present at a very low percentage (Fig. $5 C$ ). In addition, cultured astrocytes did not express p421.HB/PD-I $\alpha$ mRNA (Fig. $5 D$; very faint bands likely resulted from a few remaining oligodendrocytes in these shaken cultures). In contrast, mixed glial cultures and purified oligodendrocytes expressed all four

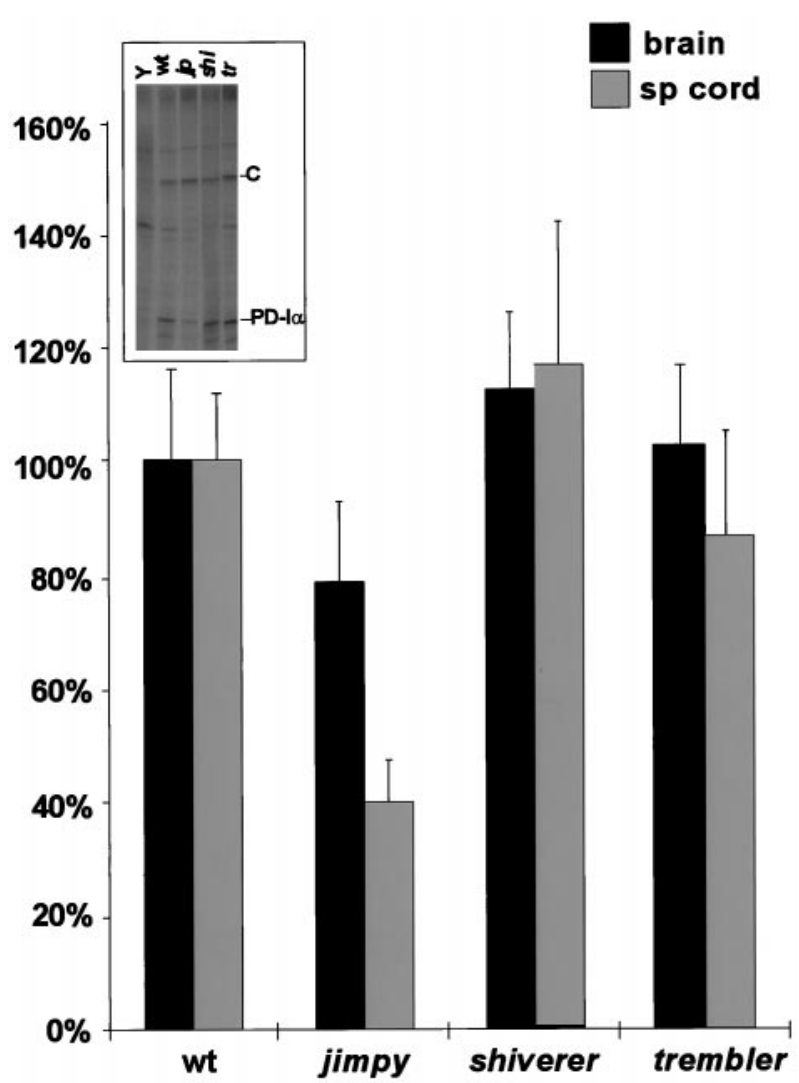

Figure 6. Characterization of p421.HB/PD-I $\alpha$ mRNA levels in dysmyelinating mouse mutants [jimpy ( jp), shiverer (shi), and trembler (tr)]. Levels of $\mathrm{p} 421 . \mathrm{HB} / \mathrm{PD}-\mathrm{I} \alpha$ mRNA present in brain and spinal cord of 21-d-old dysmyelinating mutant mice were compared with wild-type (wt) levels by RPA. Ten micrograms of total RNA were used for hybridization with ${ }^{32} \mathrm{P}$-labeled cRNA probes for p421.HB and cyclophilin. Protected fragments were analyzed in $6 \%$ denaturing acrylamide gels by phosphorimaging techniques (the inset shows a representative example of the separation of protected fragments; $C$, protected cyclophilin band; $P D-I \alpha$, protected $\mathrm{p} 421 . \mathrm{HB} / \mathrm{PD}-\mathrm{I} \alpha$ band). Three independent experiments using RNA of at least two animals each were used for statistical analysis. Amounts of protected $\mathrm{p} 421 . \mathrm{HB} / \mathrm{PD}-\mathrm{I} \alpha$ fragments were standardized by the cyclophilin values obtained in the same hybridization reaction. Wildtype mRNA levels were set to $100 \%$, and mutant levels were adjusted accordingly. Error bars represent SD.

isoforms [Fig. 5D; the additional band above the 234 bp band resulted from heteroduplex formation, as demonstrated by reannealing experiments (Wenger et al., 1991) (data not shown)]. In summary, these data suggest that the oligodendrocyte is the predominant cell type expressing the $75 \mathrm{bp}$ CNS-specific sequence.

\section{p421.HB/PD-I $\alpha$ mRNA levels are decreased in the CNS of the dysmyelinating mutant jimpy}

To assess the functional involvement of p421.HB/PD-I $\alpha$ in oligodendrocyte differentiation and myelination, we analyzed p421.HB/PD-I $\alpha$ mRNA levels in the dysmyelinating mutants jimpy, shiverer, and trembler by RPA (Fig. 6). Jimpy animals are characterized by a point mutation in the gene coding for PLP, which results in the failure of oligodendrocyte precursors to differentiate into mature oligodendrocytes. The shiverer mutation results from a deletion of a large portion of the myelin basic protein gene and in these mice oligodendrocytes begin to myelinate, but they fail to form normally compacted myelin. In addition to these CNS dysmyelinating mutants, we investigated p421.HB/ PD-I $\alpha$ mRNA levels in the CNS of the trembler mutant, in which 
a point mutation in the gene coding for the peripheral myelin protein 22 results in severe hypomyelination by Schwann cells but is without described effects on oligodendrocytes in the CNS. Animals at postnatal day 21 were selected for these experiments because of the presumed normal peak of p421.HB/PD-I $\alpha$ mRNA expression in oligodendrocytes (Fig. 3). In jimpy brains and spinal cords a pronounced decrease in $\mathrm{p} 421 . \mathrm{HB} / \mathrm{PD}-\mathrm{I} \alpha$ mRNA levels was observed, whereas changes in shiverer and trembler mutants appeared to be statistically insignificant. Because the trembler mutation is described to affect the PNS only, normal levels of p421.HB/PD-I $\alpha$ mRNA in the CNS were anticipated. Normal levels of $\mathrm{p} 421 . \mathrm{HB} / \mathrm{PD}-\mathrm{I} \alpha \mathrm{mRNA}$ in the shiverer $\mathrm{CNS}$ suggest that $\mathrm{p} 421 . \mathrm{HB} / \mathrm{PD}-\mathrm{I} \alpha$ plays a functional role at a developmental time point before myelin compaction. In that case, expression of $\mathrm{p} 421 . \mathrm{HB} / \mathrm{PD}-\mathrm{I} \alpha$ would be significantly affected in jimpy mice but less so in shiverer mice.

\section{p421.HB/PD-I $\alpha$ mRNA levels are reduced at early onset of clinical symptoms in a relapsing EAE model}

Because $\mathrm{p} 421 . \mathrm{HB} / \mathrm{PD}-\mathrm{I} \alpha$ is potentially important during myelin sheath formation, studies were begun to investigate its expression in a second type of animal model with white matter pathology, EAE, in which myelin damage is accompanied by an infiltration of inflammatory cells and changes in cytokine levels. EAE was induced with the immunodominant determinant of PLP (p139$151)$ in (SWR/SJL) $\mathrm{F}_{1}$ mice, causing a relapsing-remitting disease with a progression to chronic disability (Yu et al., 1996). $\mathrm{p} 421 . \mathrm{HB} / \mathrm{PD}-\mathrm{I} \alpha$ mRNA levels were determined at onset of clinical symptoms, at which, histologically, myelin appears to be normal, but infiltration of inflammatory cells results in an increase of various chemokines, such as interferon- $\gamma$-inducible protein and monocyte chemoattractant protein-1 (Glabinski et al., 1995). In both CNS areas, brain and spinal cord, an $\sim 25 \%$ reduction in mRNA levels coding for $\mathrm{p} 421 . \mathrm{HB} / \mathrm{PD}-\mathrm{I} \alpha$ was observed (Fig. 7). No extensive changes in p421.HB/PD-I $\alpha$ mRNA levels in the choroid plexus were noted by in situ hybridization, although further quantitative analyses are needed to confirm this. A similar reduction in mRNA levels in both CNS regions was found for PLP, the major myelin protein of the CNS (Fig. 7). These data indicate that the reduced $\mathrm{p} 421 . \mathrm{HB} / \mathrm{PD}-\mathrm{I} \alpha$ mRNA levels result from alterations in oligodendrocyte gene expression. The observed changes in oligodendrocyte mRNA levels in both brain and spinal cord and the fact that for the EAE model used in this study infiltration of cells of the immune system and demyelination at later stages of the disease occur predominantly in the spinal cord (Sobel et al., 1991), suggest a broader oligodendrocyte response than just at the site of inflammatory infiltration. In conclusion, these data indicate that during infiltration of lymphocytes, before any signs of demyelination are obvious, oligodendrocyte gene expression changes, possibly rendering these cells more susceptible for a subsequent autoimmune attack.

\section{DISCUSSION}

p421.HB/PD-I $\alpha$ represents a member of the somatomedin/phosphodiesterase family of proteins that is expressed predominantly in the CNS by oligodendrocytes, the myelin-forming cells of the CNS, and by choroid plexus epithelial cells. The tissue-specific expression of rat $\mathrm{p} 421$.HB/PD-I $\alpha$ described here is in good agreement with results published by Narita et al. (1994) and Lee et al. (1996). In addition, our detailed developmental analysis in the CNS revealed an intermediate peak of expression around the time of active myelination. Furthermore, p421.HB/PD-I $\alpha$ expres-

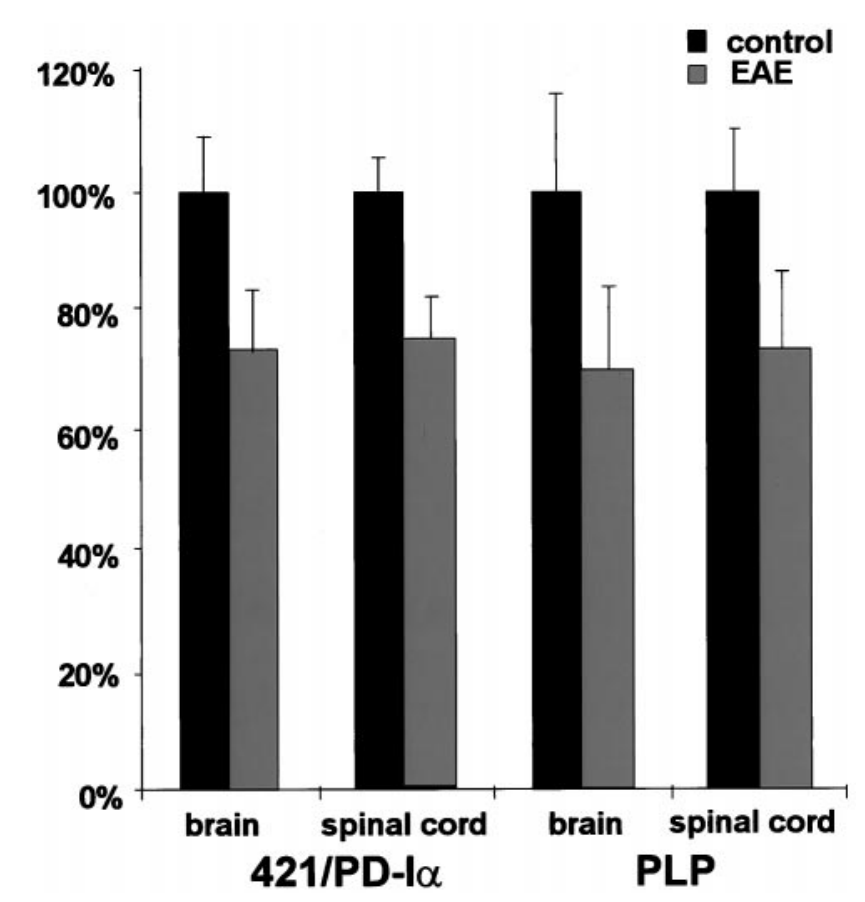

Figure 7. Characterization of $\mathrm{p} 421 . \mathrm{HB} / \mathrm{PD}-\mathrm{I} \alpha$ and PLP mRNA levels at onset of clinical symptoms in EAE. Levels of p421.HB/PD-I $\alpha$ and PLP mRNA expressed in brain and spinal cord of EAE (PLP peptide-injected) mice were compared with normal (control, BSA-injected) levels by RPA. Tissues for RNA preparation were taken from EAE mice at onset of clinical symptoms and of time-matched control animals. Ten micrograms of total RNA of each animal were used for hybridization with ${ }^{32} \mathrm{P}$-labeled cRNA probes for $\mathrm{p} 421 . \mathrm{HB}$ and PLP, each in combination with cyclophilin for normalization. Protected fragments were analyzed in $6 \%$ denaturing acrylamide gels by phosphorimaging techniques. For statistical analysis four pairs of samples (EAE vs control) were used, and levels of p421.HB/ PD-I $\alpha$ and PLP mRNA were normalized to cyclophilin values. Control mRNA levels were set to $100 \%$, and EAE mRNA levels were calculated accordingly. Error bars represent SD.

sion in the spinal cord is consistent with the postnatal expression of myelin-specific glycolipids and myelin basic protein, which are first observed most ventrally and closest to the spinal cord surface in the white matter, and then later in a patchy pattern in the gray matter, following the presumptive spatio-temporal myelination pattern of fiber tracts (Jordan et al., 1989; Schwab and Schnell, 1989). These findings, together with the demonstration of p421.HB/PD-I $\alpha$ mRNA expression in differentiated oligodendrocytes in culture, strongly suggest a role of $\mathrm{p} 421 . \mathrm{HB} / \mathrm{PD}-\mathrm{I} \alpha$ in oligodendrocyte maturation and/or myelination.

Considering the possible function of $\mathrm{p} 421 . \mathrm{HB} / \mathrm{PD}-\mathrm{I} \alpha$ expressed by oligodendrocytes, its function in epithelial cells of the choroid plexus is rather obscure. The choroid plexus represents the main source of the CSF, the composition and production of which were shown to be regulated by adenosine (Kalaria and Harik, 1986; Faraci et al., 1988). p421.HB/PD-I $\alpha$ together with ecto-5'nucleotidase (Braun et al., 1994) could very well be involved in these regulatory events, which might be essential for the maintenance of body fluid-brain barriers. Interestingly, PD-I $\alpha$ mRNA was also localized in ciliary epithelial cells, iris pigment epithelial cells, and retinal pigment epithelial cells, suggesting a common functional role in secretory epithelial cells (Narita et al., 1994). In addition, it has been suggested that choroid plexus epithelial cells are producing target-derived neurotrophic factors for innervating neurons, such as NGF, neurotrophin 4, and insulin-like growth 
factor II (Hynes et al., 1988; Timmusk et al., 1995), which would be consistent with a putative cytokine function for $\mathrm{p} 421 . \mathrm{HB} / \mathrm{PD}-\mathrm{I} \alpha$, as described for its human homolog autotaxin. Expression of a variety of cytokines by choroid plexus epithelial cells might also provide a pool of survival and regulatory factors that could insure maintenance of proper CNS function.

Differential expression of $\mathrm{p} 421 . \mathrm{HB} / \mathrm{PD}-\mathrm{I} \alpha$ isoforms, most likely generated by alternative splicing, complicates interpretation of mRNA and protein expression data. Our studies identified four isoforms of $\mathrm{p} 421 . \mathrm{HB} / \mathrm{PD}-\mathrm{I} \alpha$. In addition, sequence analysis indicates the possible existence of yet more variants (see Fig. 1). At the present time, it is unclear what functional consequences any of these alternative splicing events may have, although it appears that the 25 amino acid PD-I $\alpha$-specific sequence is expressed predominantly in oligodendrocytes and may, therefore, be crucial for $\mathrm{p} 421 . \mathrm{HB} / \mathrm{PD}-\mathrm{I} \alpha$ function during myelination. Interestingly, the 75 bp CNS-specific sequence appears to be more enriched in the optic nerve than in oligodendrocytes in culture, either reflecting a unique property of the optic nerve or demonstrating a downregulated expression of this sequence in vitro, possibly induced by altered cell-cell contact, such as between oligodendrocytes and axons.

Decreased levels of p421.HB/PD-I $\alpha$ mRNA in jimpy brains, demonstrated here by RPA, were confirmed by in situ hybridization, where we observed a decreased number of $\mathrm{p} 421 . \mathrm{HB} / \mathrm{PD}-\mathrm{I} \alpha$ mRNA-positive cells in white matter (B. Fuss, E. Shick, and W. B. Macklin, unpublished observations). These data suggest that jimpy oligodendrocytes, which remain immature, with increased rates of oligodendrocyte precursor cell proliferation and oligodendrocyte cell death (Skoff, 1995), cannot differentiate to the developmental stage at which $\mathrm{p} 421 . \mathrm{HB} / \mathrm{PD}-\mathrm{I} \alpha$ is normally expressed. From these studies we propose that expression of $\mathrm{p} 421 . \mathrm{HB} / \mathrm{PD}-\mathrm{I} \alpha$ is important for the intermediate stages of oligodendrocyte differentiation and/or early events involved in the formation of the myelin sheath, before myelin compaction. As an important future question, it remains to be seen whether the proposed functional role in myelination is related to the hypothesized functional properties of the protein in cell-cell and/or cell-extracellular matrix interactions (see above and below).

Downregulation of $\mathrm{p} 421 . \mathrm{HB} / \mathrm{PD}-\mathrm{I} \alpha$ and PLP expression in the CNS at early stages of EAE suggests an impairment of oligodendrocyte function before detectable damage of the myelin sheath. These conclusions are supported by data obtained in a virusinduced animal model for multiple sclerosis, in which inoculation of susceptible strains of mice with Theiler's encephalomyelitis virus (TMEV) induces inflammatory demyelination (Rodriguez et al., 1994). Downregulation of PLP mRNA in the spinal cord was observed preceding the development of prominent inflammation and demyelination in susceptible but not TMEV-resistant mice. These data suggest that oligodendrocyte damage caused by several different initiating events may begin with changes in myelin gene expression before lesions can be detected morphologically. These changes in gene expression could be induced by soluble factors synthesized either by infiltrating cells directly or by activated cells of the nervous system, such as astrocytes or microglia. Interestingly, it has been recently reported that autotaxin mRNA levels are downregulated after interferon- $\gamma$ treatment (Santos et al., 1996). Together with the identification of interferon- $\gamma$ receptors on oligodendrocytes (Torres et al., 1995) and a proposed role of interferon- $\gamma$ in the pathogenesis of demyelinating diseases through a direct effect on oligodendrocytes (Vartanian et al., 1995; Agresti et al., 1996), interferon- $\gamma$ represents a possible candidate cytokine that could be responsible for the above-described changes in oligodendrocyte gene expression. It must be noted, however, that we cannot exclude the possibility that the observed downregulation of $\mathrm{p} 421 . \mathrm{HB} / \mathrm{PD}-\mathrm{I} \alpha$ in the brains of EAE mice results, at least in part, from changes in choroid plexus epithelial cells. On the other hand, the data demonstrating a comparable downregulation in the spinal cord both for $\mathrm{p} 421 . \mathrm{HB} / \mathrm{PD}-\mathrm{I} \alpha$ and PLP mRNA argue for likely effects on oligodendrocyte gene expression in this model.

With regard to possible mechanisms of $\mathrm{p} 421 . \mathrm{HB} / \mathrm{PD}-\mathrm{I} \alpha$ function, it is worth mentioning that the second somatomedin $\mathrm{B}$ domain of $\mathrm{p} 421 . \mathrm{HB} / \mathrm{PD}-\mathrm{I} \alpha$, but not PC-1 or the gp130RB13-6 antigen, contains an RGD peptide sequence, which represents a binding site for several ( $\alpha_{5} \beta_{1}, \alpha_{\mathrm{IIb}} \beta_{3}$, and all or most $\alpha_{\mathrm{v}} \beta$ integrins) but not all integrin receptors (Hynes, 1992). Integrins have been identified in cultured oligodendrocytes, although the nature of the integrin subunits expressed by oligodendrocytes remains controversial (Cardwell and Rome, 1988; Malek-Hedayat and Rome, 1994; Milner and French-Constant, 1994). Therefore, p421.HB/PD-I $\alpha$ could represent an extracellular matrix ligand regulating oligodendrocyte function. On the other hand, because the primary function for the human homolog of $\mathrm{p} 421 . \mathrm{HB} / \mathrm{PD}-\mathrm{I} \alpha$, autotaxin, appears to be in motility (Stracke et al., 1993), p421.HB/PD-I $\alpha$ may very well be involved in motility and/or oligodendrocyte process extension during oligodendrocyte differentiation and identification of axons to be myelinated. In addition to the potential interaction of the $\mathrm{p} 421 . \mathrm{HB} / \mathrm{PD}-\mathrm{I} \alpha$ protein with integrins, the EF hand-like motif at the far $\mathrm{C}$-terminal end suggests that its functional properties may be regulated by $\mathrm{Ca}^{2+}$ binding. Although EF hand motifs are well known as paired domains of many $\mathrm{Ca}^{2+}$-binding intracellular proteins, such as calmodulin and parvalbumin (Babu et al., 1988), single EF hand-like motifs have been described in extracellular proteins as well. In SPARC/BM-40/osteonectin the embedding of the single EF hand motif into a larger domain was shown to be necessary for $\mathrm{Ca}^{2+}$-dependent binding to collagen IV (Maurer et al. 1995). At the present time, it is not known, whether p421.HB/ $\mathrm{PD}-\mathrm{I} \alpha$ binds to collagen IV or any other brain matrix proteins. However, such studies are clearly relevant for understanding the role of $\mathrm{p} 421 . \mathrm{HB} / \mathrm{PD}-\mathrm{I} \alpha$ in normal brain development and under pathological conditions.

The present study provides good evidence that $\mathrm{p} 421 . \mathrm{HB} / \mathrm{PD}-\mathrm{I} \alpha$ in the CNS is likely to be involved in oligodendrocyte function. In the process of oligodendrocyte maturation and/or myelin sheath formation, it may be involved in cell-cell and/or cell-extracellular matrix interactions. It will be important to establish whether different functional properties of $\mathrm{p} 421 . \mathrm{HB} / \mathrm{PD}-\mathrm{I} \alpha$ require the expression of different isoforms and to what extent expression of one or several of these isoforms plays a critical role in the ability of the oligodendrocyte to myelinate and remyelinate CNS axons.

\section{REFERENCES}

Agresti C, D’Urso D, Levi G (1996) Reversible inhibitory effects of interferon- $\gamma$ and tumor necrosis factor- $\alpha$ on oligodendroglial lineage cell proliferation and differentiation in vitro. Eur J Neurosci 8:1106-1116.

Altschul SF, Gish W, Miller W, Myers EW, Lipman DJ (1990) Basic local alignment search tool. J Mol Biol 215:403-410.

Baba H, Fuss B, Watson JB, Zane LT, Macklin WB (1994) Identification of novel mRNAs expressed in oligodendrocytes. Neurochem Res 19:1091-1099.

Babu YS, Bugg CE, Cook WJ (1988) Structure of calmodulin refined 2.2 A resolution. J Mol Biol 204:191-204.

Barres BA, Hart IK, Coles HSR, Burne JF, Voyvodic JT, Richardson WD, Raff MC (1992) Cell Death and control of cell survival in the oligodendrocyte lineage. Cell 70:31-46.

Bartsch S, Bartsch U, Dörries U, Faissner A, Weller A, Ekblom P, 
Schachner M (1992) Expression of tenascin in the developing and adult cerebellar cortex. J Neurosci 12:736-749.

Braun JS, Le Hir M, Kaissling B (1994) Morphology and distribution of ecto-5'-nucleotidase-positive cells in the rat choroid plexus. J Neurocytol 23:193-200.

Buckley MF, Loveland KA, McKinstry WJ, Garson OM, Goding JW (1990) Plasma cell membrane glycoprotein PC-1. cDNA cloning of the human molecule, amino acid sequence, and chromosomal location. J Biol Chem 265:17506-17511.

Campagnoni AT and Macklin WB (1988) Cellular and molecular aspects of myelin gene expression. Mol Neurobiol 2:41-89.

Cardwell MC, Rome LH (1988) RGD-containing peptides inhibit the synthesis of myelin-like membrane by cultured oligodendrocytes. J Cell Biol 107:1551-1559.

Chomczynski P, Sacchi N (1987) Single-step method of RNA isolation by acid guanidine thiocyanate-phenol-chloroform extraction. Anal Biochem 162:156-159.

Danielson PE, Forss-Peter S, Brow MA, Calavetta L, Douglass J, Milner RJ, Sutcliffe JG (1988) p1B15: a cDNA clone of the rat mRNA encoding cyclophilin. DNA 7:261-267.

Deissler H, Lottspeich F, Rajewsky MF (1995) Affinity purification and cDNA cloning of rat neural differentiation and tumor cell surface antigen gp130RB13-6 reveals relationship to human and murine PC-1. J Biol Chem 270:9849-9855.

Eisenbarth GS, Walsh FS, Nirenburg M (1979) Monoclonal antibodies to a plasma membrane antigen of neurons. Proc Natl Acad Sci USA 76:4913-4916.

Faraci FM, Mayhan WG, Williams JK, Heistad DD (1988) Effects of vasoactive stimuli on blood flow to choroid plexus. Am J Physiol 23:H286-H291.

Frohman MA (1994) On beyond classic RACE (rapid amplification of cDNA ends). PCR Methods Appl 4:S40-S47.

Fuss B, Wintergerst ES, Bartsch U, Schachner M (1993) Molecular characterization and in situ mRNA localization of the neural cell recognition molecule J1-160/180: a modular structure similar to tenascin. J Cell Biol 120:1237-1249.

Glabinski AR, Tani M, Tuohy VK, Tuthill RJ, Ransohoff RM (1995) Central nervous system chemokine mRNA accumulation follows initial leukocyte entry at onset of acute murine experimental autoimmune encephalomyelitis. Brain Behav Immun 9:315-330.

Hynes MA, Brooks PJ, Van Wyk JJ, Lund PK (1988) Insulin-like growth factor II messenger ribonucleic acids are synthesized in the choroid plexus of rat brain. Mol Endocrinol 2:47-54.

Hynes RO (1992) Integrins: versatility, modulation, and signaling in cell adhesion. Cell 69:11-25.

Ikenaka K, Kagawa T (1995) Transgenic systems studying myelin gene expression. Dev Neurosci 17:127-136.

Jordan C, Friedrich Jr V, Dubois-Dalqc M (1989) In situ hybridization analysis of myelin gene transcripts in developing mouse spinal cord. J Neurosci 9:248-257.

Kalaria RN, Harik SI (1986) Adenosine receptors of cerebral microvessels and choroid plexus. J Cereb Blood Flow Metab 6:463-470.

Kawagoe H, Soma O, Goji J, Nishimura N, Narita M, Inazawa J, Nakamura H, Sano K (1995) Molecular cloning and chromosomal assignment of the human brain-type phosphodiesterase I/nucleotide pyrophosphatase gene (PDNP2). Genomics 30:380-384.

Krieg PA, Melton DA (1984) Functional messenger RNAs are produced by SP6 in vitro transcription of cloned cDNAs. Nucleic Acids Res 12:7035-7056.

Kurihara T, Tohyama Y, Yamamoto J, Kanamatsu T, Watanabe R, Kitajima S (1992) Origin of brain 2',3'-cyclic-nucleotide $3^{\prime}$ phosphodiesterase doublet. Neurosci Lett 138:49-52.

Lee HY, Murata J, Clair T, Polymeropoulos MH, Torres R, Manrow RE, Liotta LA, Stracke ML (1996) Cloning, chromosomal localization, and tissue expression of autotaxin from human teratocarcinoma cells. Biochem Biophys Res Commun 218:714-719.

Lemke G (1988) Unwrapping the genes of myelin. Neuron 1:535-543.

Malek-Hedayat S, LH Rome (1994) Expression of a $\beta_{1}$-related integrin by oligodendroglia in primary culture: evidence for a functional role in myelination. J Cell Biol 124:1039-1046.

Martini R, McFarland HF (1995) Immunological aspects of experimental allergic encephalomyelitis and multiple sclerosis. Crit Rev Clin Lab Sci 32:121-182.

Maurer P, Hohenadl C, Hohenester E, Göhring, Timpl R, Engel J (1995)
The c-terminal portion of BM-40 (SPARC/osteonectin) is an autonomously folding and crystallisable domain that binds calcium and collagen IV. J Mol Biol 253:347-357.

McCarthy KD, de Vellis J (1998) 0) Preparation of separate astroglial and oligodendroglial cell cultures from rat cerebral tissue. J Cell Biol 85:890-902.

Mikoshiba K, Okano H, Tamura T, Ikenaka K (1991) Structure and function of myelin proteins. Annu Rev Neurosci 14:201-217.

Milner R, ffrench-Constant C (1994) A developmental analysis of oligodendroglial integrins in primary cells: changes in $\alpha_{\mathrm{v}}$-associated $\beta$ subunits during differentiation. Development 120:3497-3506.

Murata J, Lee HY, Clair T, Krutzsch HC, Årestad AA, Sobel ME, Liotta LA, Stracke ML (1994) cDNA cloning of the human tumor motilitystimulating protein, autotaxin, reveals a homology with phosphodiesterases. J Biol Chem 269:30479-30484.

Narita M, Goji J, Nakamura H, and Sano K (1994) Molecular cloning, expression and localization of a brain-specific phosphodiesterase I/ nucleotide pyrophosphatase (PD-I $\alpha$ ) from rat brain. J Biol Chem 269:28235-28242.

Nave KA (1994) Neurological mouse mutants and the genes of myelin. J Neurosci Res 38:607-612.

Panoskaltsis-Mortari A, Bucy RP (1995) In situ hybridization with digoxigenin-labeled RNA probes: facts and artifacts. Biotechniques 18:300-307.

Rodriguez M, Prayoonwiwat N, Howe C, Sanborn K (1994) Proteolipid protein gene expression in demyelination and remyelination of the central nervous system: a model for multiple sclerosis. J Neuropathol Exp Neurol 53:136-143.

Saccomanno CF, Bordonaro M, Chen JS, Nordstrom JL (1992) A faster ribonuclease protection assay. Biotechniques 13:846-850.

Santos AN, Riemann D, Santos AN, Kehlen A, Thiele K, Langner J (1996) Treatment of fibroblast-like synoviocytes with IFN- $\gamma$ results in down-regulation of autotaxin mRNA. Biochem Biophys Res Commun 229:419-424.

Schwab ME, Schnell L (1989) Region-specific appearance of myelin constituents in the developing rat spinal cord. J Neurocytol 18:161-169.

Skoff R (1995) Programmed cell death in the dysmyelinating mutants. Brain Pathol 5:283-288.

Sobel RA, Tuohy VK, Lees MB (1991) Parental MHC molecule haplotype expression in $(\mathrm{SWRxSJL}) \mathrm{F}_{1}$ mice with acute experimental allergic encephalomyelitis induced with two different synthetic peptides of myelin proteolipid protein. J Immunol 146:543-549.

Sorg BA, Smith MM Campagnoni AT (1987) Developmental expression of the myelin proteolipid protein and basic protein mRNAs in normal and dysmyelinating mutant mice. J Neurochem 49:1146-1154.

Stracke ML, Liotta LA, Schiffmann E (1993) The role of autotaxin and other moltility stimulating factors in the regulation of tumor cell motility. In: Cell behaviour: adhesion and motility (Jones G, Wigley C, Warn R, eds), pp 197-214. Cambridge, UK: Company of Biologists.

Timmusk T, Mudo G, Metsis M, Belluardo N (1995) Expression of mRNAs for neurotrophins and their receptors in the rat choroid plexus and dura mater. Mol Neurosci 6:1997-2000.

Torres C, Aranguez I, Rubio N (1995) Expression of interferon- $\gamma$ receptors on murine oligodendrocytes and its regulation by cytokines and mitogens. Immunology 86:250-255.

Tsunoda I, Fujinami RS (1996) Two models for multiple sclerosis: experimental allergic encephalomyelitis and Theiler's murine encephalomyelitis virus. J Neuropathol Exp Neurol 55:673-686.

Tuohy VK, Lu Z, Sobel RA, Laursen RA, Lees MB (1989) Identification of an encephalitogenic determinant of myelin proteolipid protein for SJL mice. J Immunol 142:1523-1526.

van Driel IR, Goding JW (1987) Plasma cell membrane glycoprotein PC-1. Primary structure deduced from cDNA clones. J Biol Chem 262:4882-4887.

Vartanian T, Li Y, Zhao M, Stefansson K (1995) Interferon- $\gamma$-induced oligodendrocyte cell death: implication for the pathogenesis of multiple sclerosis. Mol Med 7:732-743.

Wenger RH, Ayane M, Bose R, Köhler G, Nielsen PJ (1991) The genes for a mouse hematopoietic differentiation marker called the heat-stable antigen. Eur J Immunol 21:1039-1046.

Yu M, Nishiyama A, Trapp BD, Tuohy VK (1996) Interferon- $\beta$ inhibits progression of relapsing-remitting experimental autoimmune encephalomyelitis. J Neuroimmunol 64:91-100. 